\title{
Data-PSST Seminar Series Report
}

\author{
ABIGAIL BLYTH, Aberystwyth University
}

\begin{abstract}
This is a report into a series of multi-disciplinary seminars funded by the Economic and Social Research Council (ESRC) over an 18 month period. Following the Snowden revelations in June 2013, assessing transparency, security, privacy, surveillance and trust have become integral themes, something the seminar series has sought to achieve by creating a series of key policy recommendations and further research questions.
\end{abstract}

\section{KEYWORDS}

Transparency, surveillance, trust, privacy, multi-disciplinary

\section{Introduction}

Over 18 months, seminars funded by the ESRC and organised by Vian Bakir took place at Universities across the UK, which brought together a team of multi-disciplinary experts from academia, activists, journalism and the policy world. This allowed for an engaging and multifaceted debate, combining academic and practical perspectives to 'Debating and Assessing Transparency Arrangements - Privacy, Security, Surveillance and Trust' (Data-PSST). Each seminar has sought to address a different but inter-related theme connected to Data-PSST, and has resulted in a series of policy recommendations being created.

\section{Contextualisation}

Although whistle-blowing is not a new phenomenon, with Peter Wright attempting to publish Spycatcher in 1987, it has returned to the public debate following unauthorised disclosures by Chelsea Manning and Edward Snowden. In 2010, Private Manning disclosed via WikiLeaks American military activities in the Iraq war, including a video of a US helicopter killing Reuters journalists and civilians ${ }^{1}$. Three years later, Edward Snowden revealed in The Guardian the extent to which the US via its National Security Agency (NSA), described as one of the most secretive intelligence organisation ${ }^{2}$, and its allies - predominantly the UK were spying on citizens and collecting information from private companies including Google, Apple and Facebook ${ }^{3}$.

\footnotetext{
${ }^{1}$ Free Chelsea Manning, What WikiLeaks Revealed, Available From: https://www.chelseamanning.org/learnmore/what-did-wikileaks-reveal (Accessed 11th April 2016)

${ }^{2}$ Greenwald, G, No Place To Hide - Edward Snowden, the NSA and the US Surveillance State, (New York, Metropolitan Books, 2014), p. 20

3 The Guardian, UK gathering secret intelligence via covert NSA operation, Available From: https://www.theguardian.com/technology/2013/jun/07/uk-gathering-secret-intelligence-nsa-prism (Accessed 11th April 2016)
} 
Such cooperation is unsurprising as the trans-Atlantic intelligence sharing relationship dates back to $1917^{4}$ and operation Squeaky Dolphin ${ }^{5}$ just represents the latest phase. The Manning and Snowden revelations have once again sparked debates surrounding privacy, security and surveillance which have continued to dominate the British media ${ }^{6}$ and public opinion. Therefore, it is necessary to comprehend how transparency, however it manifests itself, has affected surveillance, privacy and trust, a central aim of the seminar series ${ }^{7}$.

\section{Seminar Series}

\section{Seminar 1 - Transparency Today}

The first seminar took a theoretical stance on the subject, allowing for the ensuing debates to be based within clear understanding of the topic area, and what was meant by key terms such as surveillance and sousveillance. The latter was termed by Steve Mann to refer to a reversed panoptican ${ }^{8}$ and is of increasing importance. However it is increasingly used by the public via social media and wearable technology which arguably encourages the continued watching of other's activities. This led to a discussion surrounding the possibility of sousveillance becoming surveillance. Due to the ever closer relations between technology companies and governments, further demonstrated in the Snowden disclosures ${ }^{9}$, there is undeniably the possibility of data, collected and stored via sousveillance, being used as surveillance. The seminar highlighted how such cooperation is not a new phenomenon but based upon the blurring between the state and the private sector, in part due to the post $9 / 11$ desire to ensure national security. One clear example that Kirsty Ball discussed is the creation of E-Borders under the 2006 Immigration, Asylum and Nationality Act ${ }^{10}$.

The discussion led to a policy recommendation of ensuring that politics students and academics are technologically aware, and that computer scientists are aware of the political ramifications of their work. This was a theme highlighted in subsequent seminars, demonstrating its importance, not only for computer scientists and academics, but also for end-users, such as policy-makers and journalists.

\section{Seminar 2 - Debating the Technical and Ethical Limits of Secrecy and Privacy}

The public continue to place large amounts of information online whether through social media or cloud storage, unaware of the potential ramifications, suggesting a lack of awareness of technological matters which affect them. Perhaps this is an effect of the overly

\footnotetext{
${ }^{4}$ Beach, J, 'Origins of the special intelligence relationship? Anglo-American intelligence cooperation on the Western Front, 1917 - 1918', Intelligence and National Security, 22/2, (2007), p. 245

5 BBC News, Snowden Leaks: GCHQ 'spied on Facebook and YouTube' Available From: http://www.bbc.co.uk/news/technology-25927844 (Accessed 28th April 2016)

6 The Guardian, Why print newspapers remain the dominant media power in Britain, Available From: http://www.theguardian.com/media/greenslade/2015/feb/16/why-print-newspapers-remain-the-dominant-mediapower-in-britain (Accessed 28th April 2016)

7 Bangor University, DATA-PSST! ESRC Seminar Series 2015-16 - Home, Available From: http://datapsst.bangor.ac.uk/ (Accessed $28^{\text {th }}$ March 2016)

${ }^{8}$ Mann, S, Nolan, J, Wellman, B, 'Sousveillance: Inventing and Using Wearable Computing Devices for Data Collection in Surveillance Environments', Surveillance and Society, 1/3 (2003), p. 332

${ }^{9}$ BBC News, Snowden Leaks: GCHQ 'spied on Facebook and YouTube' Available From: http://www.bbc.co.uk/news/technology-25927844 (Accessed 28th April 2016)

10 Liberty - Protecting Civil Liberties Promoting Human Rights, E-Borders, Available From: https://www.liberty-human-rights.org.uk/human-rights/asylum-and-borders/e-borders (Accessed 1st May 2016)
} 
complex language utilised when discussing technology. The lack of understanding is further demonstrated as the Information Commissioners Office (ICO) stated that despite the thousands of complaints they receive every year, few relate to surveillance ${ }^{11}$. This suggests a substantial lack of understanding surrounding surveillance, privacy and trust which may occur via the arguably lacklustre actions of the Intelligence and Security Committee (ISC) in overseeing British intelligence, as they are within the 'ring of secrecy'12. This could be overcome by members of the public sitting on the ISC which may increase trust in the ISC's oversight capabilities, and was one of the policy recommendations created.

However, in the UK, a clear understanding of who the British Intelligence Services are is absent, which could further confusion surrounding these matters, and demonstrates the necessity for public perceptions of intelligence to be analysed. One key way in which public understanding could be furthered is through greater academic engagement. As the seminar series has highlighted, academia wants to engage with policy-makers and end-users; however, this sentiment is not always reciprocated and is an obstacle to overcome in ensuring public engagement and awareness, a theme highlighted by Vian Bakir and Madeline Carr.

\section{Seminar 3 - Media Agenda Building}

The theme of public awareness was also evident in the third seminar, demonstrating its importance. One key aspect of the Snowden leaks was how surveillance and intelligence activity is not confined by national borders anymore. This should not be overly surprising as those organisations that western intelligence seek to counter nowadays tend to be non-state actors and don't adhere to national borders. Thus, as Mark Phythian stated, there are likely to be numerous other actors involved in ensuring national security ${ }^{13}$. However, the extent to which actors are involved in this process remains unclear, perhaps due to media agenda building within the mainstream media.

This was a theme that Christopher Hird and Richard Keeble highlighted - the differences between what the mainstream and the alternative media report. For mainstream media journalists, external influences may dictate the nature of their story, which could include the intelligence services providing information to them. Although it is possible to argue that this is in fact a way in which the Intelligence Services are seeking to engage with the public, concerns were articulated within the seminar about how the Intelligence Services are influencing the media agenda. Linked to this is how journalists are able to assess whether information they have gathered could damage national security. This becomes particularly problematic in the British context as consecutive governments have failed to provide a definition of national security. ${ }^{14}$ This led to a clear policy recommendation being formulated, that journalists should receive specific training in relation to intelligence matters.

\footnotetext{
${ }^{11}$ Bangor University, DATA-PSST! ESRC Seminar Series 2015-16 - Reports, Seminar Summaries and Policy Recommendations - Seminar 2 link to summary, Available From: http://data-psst.bangor.ac.uk/policy.php.en (Accessed 28th April 2016)

12 Glees, Anthony, Davies, H, J, Phillip, Morrison, N, L, John, The Open Side of Secrecy, Britain's Intelligence and Security Committee, (London, Social Affairs Unit, 2006), p. 19

13 Data-PSST!, Blog - Seminar 3 Position Statement: Professor Mark Phythian, Available From: http://datapsst.blogspot.co.uk/2015/07/prof-mark-phythian-politics.html (Accessed 6th July 2015)

${ }^{14}$ Security Service, What Is National Security, Available From: https://www.mi5.gov.uk/home/about-us/whatwe-do/protecting-national-security.html (Accessed 16th October 2015)
} 


\section{Seminar 4 - Visible Mediations of Transparency}

The theme of public awareness of surveillance continued to dominate the discussion at the fourth seminar. Despite transparency and surveillance being part of everyday society, the public only become aware of it through scandals, suggesting that the government's rhetoric fails to effectively engage with the public and other solutions should be discovered. This could occur via artists and activists as visual diagrams, and examples of surveillance may shock and resonate with the public more than technical information. This theme was highlighted by Zach Blas, who had been working on a project revolving around masks due to the emphasis upon the face becoming a mode of governmentality via biometric systems ${ }^{15}$.

The seminar raised an important but overlooked point; surveillance is not a new phenomenon and has been happening for hundreds of years. Perhaps one the earliest examples is the American government providing smallpox infected blankets to Native Americans ${ }^{16}$. What has changed however is the technology utilised. When discussing surveillance, Andy Mcstay highlighted its London-centric nature, suggesting a technological feudal system.

\section{Seminar 5 - Tackling Transparency beyond the Nation State}

Although examining transparency at an international level, some themes previously discussed were highlighted again in the fifth seminar, such as governments' reliance on private companies, something Peter Mantello analysed in relation to information flows. As the police do not have their own software creators, they are reliant upon private companies to provide the software they use on a daily basis. This is disturbing, as it is giving ever greater power to private businesses; however, it is not something to which there is a clear response. The discussion then examined how the work they undertake, along with the military and intelligence services, has become increasingly blurred due to a post 9/11 emphasis upon preemption. From a law enforcement perspective, this is problematic, as they are highly reliant upon evidence to convict in court.

Discussion then focused on private businesses and continued technological advances, which are used in a myriad of ways. Joseph Connor explained how companies are furthering the capabilities of facial recognition software so an individual's emotions can be ascertained. Despite its numerous advantages, there are concerns about how the collected emotional data is stored and who can access it. Eneken Tikk-Ringas stated it would be impossible to have an international mandate on such themes, as each country has a unique culture and ideology which affects such decisions, a theme of paramount importance but continually overlooked.

\section{Conclusion}

This report has provided an overview of the multi-disciplinary ESRC Data-PSST seminar series. Each seminar has created a plethora of policy recommendations, which are available on the Data-PSST website ${ }^{17}$. This has provided for a wider understanding on the themes

\footnotetext{
15 Goldsmith's University, Staff - Dr Zach Blas, Available From: http://www.gold.ac.uk/visualcultures/staff/blas-zach/ (Accessed $11^{\text {th }}$ September 2015)

${ }^{16}$ Indian Country Today Media Network, American History Myths Debunked: The Indians Weren't Defeated by White Settlers, Available From: http://indiancountrytodaymedianetwork.com/2012/05/20/american-historymyths-debunked-indians-werent-defeated-white-settlers-113869 (Accessed 28th April 2016)

${ }^{17}$ Bangor University, DATA-PSST! ESRC Seminar Series 2015-16 - Reports, Seminar Summaries and Policy Recommendations, Available From: http://data-psst.bangor.ac.uk/policy.php.en (Accessed 28th April 2016)
} 
examined, not only from an academic perspective, but also from end-users. All seminars have raised the necessity for the public to be aware of the themes discussed, but there continue to be problems in how this should occur, a theme the final seminar will address in June 2016.

\section{References}

Bangor University, DATA-PSST! ESRC Seminar Series 2015-16 - Home, Available From: http://data-psst.bangor.ac.uk/ (Accessed 28 ${ }^{\text {th }}$ March 2016)

Bangor University, DATA-PSST! ESRC Seminar Series 2015-16 - Reports, Seminar Summaries and Policy Recommendations, Available From: http://datapsst.bangor.ac.uk/policy.php.en (Accessed 28th April 2016)

Bangor University, DATA-PSST! ESRC Seminar Series 2015-16 - Reports, Seminar Summaries and Policy Recommendations - Seminar 2 link to summary, Available From: http://data-psst.bangor.ac.uk/policy.php.en (Accessed 28th April 2016)

BBC News, Snowden Leaks: GCHQ 'spied on Facebook and YouTube' Available From: http://www.bbc.co.uk/news/technology-25927844 (Accessed 28th April 2016)

Beach, J, 'Origins of the special intelligence relationship? Anglo-American intelligence cooperation on the Western Front, 1917 - 1918', Intelligence and National Security, 22/2, (2007), pp. $229-249$

Data-PSST!, Blog - Seminar 3 Position Statement: Professor Mark Phythian, Available From: http://data-psst.blogspot.co.uk/2015/07/prof-mark-phythian-politics.html (Accessed 6th July 2015)

Fairfax, J, 'The press: Providing the protective shield to community interests,' in Media Values - Inspired by Bill Porter; Founder of the International Communications Forum, edited by Richard Lance Keeble, (Leicester, Troubadour Publishing, 2010), pp. 71 - 78

Free Chelsea Manning, What WikiLeaks Revealed, Available From: https://www.chelseamanning.org/learn-more/what-did-wikileaks-reveal (Accessed 11th April 2016)

Gill, P, and Phythian, M, Intelligence in an Insecure World, Second Edition, (Cambridge, Polity Press, 2012)

Glees, Anthony, Davies, H, J, Phillip, Morrison, N, L, John, The Open Side of Secrecy, Britain's Intelligence and Security Committee, (London, Social Affairs Unit, 2006)

Goldsmith's University, Staff-Dr Zach Blas, Available From: http://www.gold.ac.uk/visualcultures/staff/blas-zach/ (Accessed 11 ${ }^{\text {th }}$ September 2015)

Heald, $\mathrm{H}$, 'How the media can be the heralds of a "new world order",' in Media Values Inspired by Bill Porter; Founder of the International Communications Forum, edited by Richard Lance Keeble, (Leicester, Troubadour Publishing, 2010), pp. 57 - 62

Indian Country Today Media Network, American History Myths Debunked: The Indians Weren't Defeated by White Settlers, Available From: http://indiancountrytodaymedianetwork.com/2012/05/20/american-history-mythsdebunked-indians-werent-defeated-white-settlers-113869 (Accessed 28th April 2016) 
Greenwald, G, No Place To Hide - Edward Snowden, the NSA and the US Surveillance State, (New York, Metropolitan Books, 2014)

Keeble, R, 'Words as Weapons: A History of War Reporting - 1945 to the present,' in The Handbook of Global Communication and Ethics, Volume 1, edited by Robert. S. Fortner and P. Mark Fackler, (Chichester, Wiley-Blackwell, 2011), pp.193-214

Liberty - Protecting Civil Liberties Promoting Human Rights, E-Borders, Available From: https://www.liberty-human-rights.org.uk/human-rights/asylum-and-borders/e-borders (Accessed 1st May 2016)

Machon, A, Spies, Lies and Whistleblowers, MI5, MI6 and the Shayler Affair, (Lewes, The Book Guild, 2005)

Mann, S, Nolan, J, Wellman, B, 'Sousveillance: Inventing and Using Wearable Computing Devices for Data Collection in Surveillance Environments', Surveillance and Society, 1/3 (2003), pp. $331-355$

Phythian, M, 'The British Experience with Intelligence Accountability', in Secret Intelligence, A Reader, edited by Christopher Andrew, Richard J Aldrich and Wesley K. Wark (Abingdon, Routledge, 2009) pp. 337-357

Security Service, What Is National Security, Available From: https://www.mi5.gov.uk/home/about-us/what-we-do/protecting-national-security.html (Accessed 16th October 2015)

Surprise Project, 'Citizen Summits on Privacy, Security and Surveillance: Synthesis Report', (European Union, August 2014)

The Guardian, UK gathering secret intelligence via covert NSA operation, Available From: https://www.theguardian.com/technology/2013/jun/07/uk-gathering-secret-intelligencensa-prism (Accessed 11th April 2016)

The Guardian, Why print newspapers remain the dominant media power in Britain, Available From: http://www.theguardian.com/media/greenslade/2015/feb/16/why-print-newspapersremain-the-dominant-media-power-in-britain (Accessed 28th April 2016)

The Times, Snowden leaks 'worst blow to British intelligence ever', Available From: http://www.thetimes.co.uk/tto/news/uk/defence/article3892012.ece (Accessed 8th June 2014)

Wright, P, Spycatcher, The Candid Autobiography of a Senior Intelligence Officer, (Penguin Books Australia Ltd, Ringwood, 1987)

Abigail Blyth is a PhD student in the International Politics, Aberystwyth University, funded by the Economic and Social Research Council. Her research focuses upon Intelligence accountability and how the public become aware of such issues and matters surrounding the British Intelligence Services. Abigail is active in the field outside of her $\mathrm{PhD}$ and this year is co-convenor of the Security Research Group at Aberystwyth University which has organised numerous high profile lectures and events. She has also been involved in the ESRC funded project - Debating and Assessing Transparency Arrangements - Privacy, Security, 
Surveillance and Trust and has been involved in writing up seminar summaries and policy recommendations.

Email: abb10@aber.ac.uk 